\title{
Marxismo contra positivismo, de Michael Löwy
}

Tradução de Reginaldo Di Piero. Sáo Paulo: Cortez, 2018. 159 p.

\author{
Aline Belle Legramandi \\ Mestranda em Educação (PPGE-UNINOVE). Bolsista Capes/Prosup. \\ Especialista em Literatura Brasileira e Portuguesa. \\ profalinebelle@hotmail.com
}

A primeira obra do mundialmente respeitado sociólogo brasileiro Michael Löwy, publicada no Brasil em 1975, Marxismo contra positivismo, recebe nova reedição após muitos anos ausente do mercado editorial. Apesar de náo ser inédita, a reedição sofreu alguns ajustes que lhe conferem frescor, como a retirada dos textos sobre Rosa Luxemburgo e a introduçấo de um ensaio que se associa melhor às proposiçôes da publicação, que contém sete ensaios. Está nesta obra, como o próprio autor informa no prefácio do livro, a plântula do que viria a ser um de seus trabalhos mais célebres: As aventuras de Karl Marx contra o Barão de Münchhausen - marxismo e positivismo na sociologia do conhecimento, também publicado pela editora Cortez.

Para apresentar a temática central da obra, Objetividade da ciência e ponto de vista de classe nas ciências sociais, o primeiro ensaio, começa questionando se é possível ser objetivo nesse campo da produção cientifica, uma vez que o ponto de vista do pesquisador ou de uma classe social constitui elemento fundamental para as ciências sociais. Para resolver esse impasse, que existe há quase dois séculos, a proposta de Löwy é romper epistemologicamente com o Positivismo por intermédio do Marxismo. A partir daí o autor percorre as principais matrizes da Sociologia do Conhecimento e suas correntes mais proeminentes.

O positivismo tem espaço maior no primeiro ensaio, pois, para Löwy, ainda hoje as ciências sociais estão eivadas de correntes neopositivistas, em especial o conhecimento produzido nos Estados Unidos. O positivismo é explicado e criticado desde suas origens, a começar pela perspectiva teórica de seu fundador, Auguste Comte, que propóe a invariabilidade das leis científicas, seja nas ciências naturais seja nas sociais. $O$ autor segue percorrendo a Sociologia de Durkheim e centra-se nas contradiçóes de 
Max Weber. Os grandes avanços para a área que o historicismo conservador e relativista trouxeram também ganham páginas na obra. Finaliza esse ensaio apresentando Karl Marx, filósofo e sociólogo alemão, que deu origem ao nome da terceira e última matriz da Sociologia do Conhecimento.

No segundo ensaio, Weber e Marx: rotas críticas sobre um diálogo implícito, há o empenho em contra-argumentar o positivismo weberiano, da mesma forma que Weber, em A Ética Protestante e o Espirito do Capitalismo, considerada a maior obra 'anti-Marx', faz com o materialismo histórico marxista. Analisando as fontes para sustentar a argumentação weberiana, Löwy se propóe a destituí-la de coerência e desarmonizá-la: ao dissertar e atribuir o sucesso capitalista norte-americano exclusivamente ao protestantismo desse país, Weber comete o erro de desconsiderar a questão da primazia. Contudo, é necessário relembrar que o ensaio não trata de discutir a influência do capitalismo sobre a ética puritana ou o inverso, mas de assinalar manobras pouco convencionais de que Weber fez uso para suprir a oposição a Marx, ou, nas palavras de Löwy: "a necessidade da imagem de um São Jorge acadêmico [Weber] que esmague o Dragão marxista.” (p.44)

O próximo ensaio, Homem e sociedade na obra do jovem Marx, está dividido em três partes. Na primeira, intitulada Homem e sociedade no pensamento social do século XIX, tem a proposta de trazer ao conhecimento do leitor os momentos em que a burguesia, antes considerada revolucionária, passa a se apropriar de "teorias do homem", o jusnaturalismo e o contratualismo, para sua enunciação econômico-social. Löwy alerta que essa atitude pretensamente revolucionária se torna conservadora a fim de manter a classe burguesa no poder e que o triunfo dessa empreitada se sustenta no discurso positivista da época. A natureza social do homem segundo o jovem Marx (1841-1846), segunda parte desse ensaio, apresenta as primeiras produçôes de Karl Marx, a iniciar por sua tese de doutorado e outras publicaçôes que pretendem finalizar a objeção hegeliana entre indivíduo e Estado e a divisão entre homem e cidadão, dessa forma demonstrando como tais reflexóes publicadas fomentaram o acesso de Marx ao comunismo. Na terceira e última parte, O comunismo, realização do "Homem Social", é exposto o pensamento crítico que visa denunciar as formas de alienação do homem e da sociedade, formas muito propícias aos interesses burgueses que o jovem filósofo alemão combate com o comunismo e sua concepção da natureza social do homem. 
Ainda é discutida a alienação a que está sujeita a classe trabalhadora, no modo de produção capitalista, em $O$ humanismo historicista de Marx ou reler "O capital", todavia, esse não é o foco do quarto ensaio. Nele, Löwy dispóe-se a defender o humanismo de Marx das investidas de Louis Althusser e de sua tese de que o marxismo seria "anti-humanista". Trata-se de esclarecer os equívocos de tradução e de interpretação daquele que é considerado um dos mais influentes intérpretes contemporâneos de Karl Marx, pois, de acordo com Löwy, Althusser cometeu e difundiu na sociedade científica alguns impropérios. A denúncia de que o homem é dominado pelas coisas e a desumanidade dos modos de produçáo trabalhadas em $O$ capital preludiam a discussão e se tornam pilares de sustentação da argumentação de que há humanismo nessa obra, porém, um humanismo que não admite verdades eternas ou esferas exteriores à experiência humana, caso contrário, estaríamos perante uma alienação religiosa. $\mathrm{O}$ marxismo, ao se distinguir do humanismo burguês pelo ponto de vista do proletariado e ao se constituir na perspectiva do materialismo históricodialético impossibilita, na argumentação de Löwy, a tese do anti-humanismo marxista e as incongruências que surgem da leitura do "discurso silencioso" que são a base para as proposiçóes de Althusser.

Marx e a Revolução Espanhola (1845-1856), além de proporcionar algumas pistas para um campo de estudo e investigação sobre o pensamento marxista ainda pouco explorado, debruça-se sobre os artigos de Marx publicados no New York Daily Tribune, que Löwy divide em três categorias: correspondência sobre a revoluçáo de I854, sendo que a primeira missiva data de 04 de julho desse ano; artigos de fundo do New York Daily Tribune, que dos onze textos escritos teve apenas oito publicados, e Correspondências sobre a Revolução de 1856, publicadas no mesmo periódico. A breve apresentação dessa revisão da literatura é acompanhada de uma análise dos artigos e correspondências que exibe o panorama histórico e as disputas sociopolíticas que regiam a revolução na Espanha. Conclui que a falta de amadurecimento das classes sociais espanholas foi um dos motivos que causou a traição da burguesia liberal; contudo, não há pessimismo, pois Marx vislumbra esperança numa revolução socialista advinda de países subdesenvolvidos como a Espanha daquela época.

Lenin, um dos principais atores da Revoluçáo Russa de 1917, tem o percurso da evolução de seu pensamento explorado no quinto ensaio, $D a$ 
grande lógica de Hegel à estação finlandesa de Petrogrado. Desde sua inicial e volátil simpatia pelo marxismo clássico de Plekhanov, antes de I9I4, o corte de I9I4, até às teses de abril de I9I7, que discorriam, essencialmente, sobre a transição entre a primeira etapa da revolução e a segunda etapa russa, toma-se ciência da transformação do marxismo tradicional ao leninismo, o que não acontece sem que o leitor tenha o contexto histórico permeando e ilustrando de que forma Lênin conseguiu sair da teoria rumo à aplicação das proposiçóes de Marx e Hegel na Rússia, apesar da flutuante burguesia. É notório o esforço empreendido por Löwy para que se desfaça a impressão de que o revolucionário russo pilhou a lógica de Hegel para desenvolver as teses de abril de I9I7.

O destaque do livro é o ensaio Gramsci e Lukács: em direção a um marxismo antipositivista, que encerra a obra. Esse texto já havia sido publicado em Romantismo e messianismo: ensaios sobre Lukács e Walter Benjamin, outra obra do sociólogo que está esgotada há muito tempo. Como se sabe, o marxismo ocidental tem como seus fundadores o filósofo italiano e o húngaro, são eles os intendentes da exegese humanista-historicista e antipositivista do marxismo. Não haver indícios de que ambos se conheceram e se influenciaram trata-se, para Löwy, de uma questão secundária. O que importa delinear e comprovar nessa parte do livro é a concomitância das concepçóes de cada pensador, explorando aquilo que os aproxima, como o fim do período neo-kantiano de Lukács, expresso no artigo $O$ bolchevismo como problema moral, de I9I8, e que tem as mesmas ideias centrais em A Revolução contra O Capital, que Gramsci divulgou em 1917. Porém, a honestidade intelectual de Löwy não permite que fique sem a ressalva da existência de pontos de distanciamento entre Gramsci e Lukács, tal como o que diz respeito aos estilos e conteúdos.

Embora não pareça haver em Marxismo contra positivismo uma resposta assertiva para a questão inicial do livro - é possível objetividade nas ciências sociais? -, fica claro, após a leitura, que para Michael Löwy é por meio das teorias de Karl Marx e de seu ponto de vista voltado para a classe revolucionária, o proletariado, que se tem o modo mais provável de obtenção da verdade objetiva, pois é "o único ponto de vista social que permite apreender esse caráter transitório do capitalismo ultrapassando o 'horizonte das perspectivas' burguesas." (p.96) Assim, parece possível perceber que há um certo positivismo em Löwy ao fazer essa afirmação. Entretanto, 
é compreensível o tom positivista dessa declaração, pois também se percebe, durante a leitura, que a ciência social não é livre de julgamentos de valor ou possuidora de neutralidade, já que não se pode eliminar a ideologia e a utopia presentes nas teorizaçóes dos diversos pensadores, marxistas ou positivistas. Afinal, as questóes abordadas surgiram a partir do ponto de vista desses filósofos e dos contextos históricos e políticos que vivenciaram. Enfim, Marxismo contra positivismo pode não atender ao público leigo e que deseja um primeiro contato com Marx, entretanto, os ensaios trazem grandes contribuiçóes e têm relevância para aqueles que já possuem alguma noção das matrizes da Sociologia do Conhecimento, sendo, para este público, uma obra competente, com linguagem acadêmica não enfastiante, em que se pode intensificar, principalmente, o estudo das concepçóes e evoluçóes do pensamento marxista a partir das reflexóes de um intelectual brasileiro que, não por acaso, é muito reverenciado no meio acadêmico. 